\title{
Rethinking the Role of Monetary Policy and Wage Bargaining in a World Without the Real Balance Effect
}

\author{
Sebastian Dullien*
}

\begin{abstract}
In standard macroeconomic models (new classical, AS-AD, monopolistic competition etc.) monetary policy determines the price level. Output and employment are determined in the labour market where nominal wages are set (possibly under the influence of unions), which together with the price level yield real wages. This paper shows that including nominal wages instead of real balances in the aggregate demand function of a standard monopolistic competition model changes this conclusion completely. In a model with micro-founded investment decisions, wage setters now control the price level. Monetary policy determines output and employment. Neither actor can influence real wages and profits, which are determined by the degree of monopolisation. Further, this conclusion fits well the stylised facts of the Euro area and provides an explanation for high unemployment in Europe.

JEL classifications: E6I, E64, ES2
\end{abstract}

Keywords: monetary policy, wage bargaining, unemployment, heterodox economics

\section{Introduction}

For most of the last quarter century there has been a broad consensus in macroeconomics. After the breakdown of the Keynesian revolution, the fall of the Samuelson and Solow (1960) Phillips curve as a policy tool and the triumph of Lucas' (1976) rational expectation revolution, the role of monetary policy and nominal wage contracts in macroeconomic

* Financial Times Deutschland. I thank two anonymous referees for their helpful remarks.

Correspondence address:

Dr. Sebastian Dullien, Financial Times Deutschland, Friedrichstr. 7I, IOII7 Berlin, Germany, e-mail: dullien@web.de

Received 21 Jan 2006, accepted 2 Jul 2006

C INTERVENTION 3 (2), 2006, 279-304 
models has been widely undisputed: ${ }^{\mathrm{I}}$ the real wage and thus employment and output are determined in the labour market, while inflation is determined by the central bank's monetary policy. Any attempt by the central bank to push employment above what grinds out as the labour market equilibrium only leads to accelerating inflation. In both the medium and long run, monetary policy cannot influence output and employment.

Frictions in the labour market can increase the real wage contracted and thus decrease output and employment. One of such possible frictions would be a monopoly trade union bargaining for economy-wide wages. As the trade union would use its monopoly power to extract higher real wages than were paid in a competitive labour market, output and employment are lower than in the competitive labour market set-up (Burda/ Wyplosz 1997: I5O f.). A possibility to increase output and employment in this world would be to lower the unions' bargaining power. Many of the labour market reforms discussed in Europe (e.g. in Sinn 2003) aim at exactly achieving a decrease in union power and thus lower nominal wages. This is even true for instruments which also aim at reducing the reservation wage, such as cutting unemployment benefits: as lower benefits make unemployment more unpleasant for the unemployed, this might also increase the union members' fear of unemployment and thus lower the unions' willingness to bargain for high wages which might result in higher unemployment.

In this paper, I will show that by altering a small assumption of standard macroeconomic models, namely dropping real balances from the aggregate demand function, these conclusions change completely. In this case neither employment nor output are any longer determined in the labour market, but by aggregate demand. Moreover, real wages cannot be influenced anymore by a variation of nominal wages. Instead, economic parameters like the degree of monopolisation and the weight of labour in the production function determine real wages. When introducing a monopoly union into this model, there will be a wide range of equilibria in labour and goods markets (with a wide range of different levels of output and employment) in which prices are stable. The monopoly union is not able to influence real wages or output anymore. It is then in reasonable extent up to monetary policy to chose the level of output and employment.

This paper is structured as follows: In section 2, I quickly review the distribution of macroeconomic responsibilities between unions and the central bank in standard textbook theory, i.e. neoclassical theory. In this section, I also explain the role the real balance effect plays in standard theory. In section 3, I then argue that there are good theoretical reasons to remove real balance effects from macroeconomic models. In section 4, I consequently present a model of monopolistic competition in which aggregate demand is not a function of real balances, but of income streams. Section 5 highlights what happens in such a world if wage bargaining is either highly monopolised or highly coordinated, which can be argued to be the case for the core of the Euro area. Section 6 presents a different set of macroeconomic responsibilities for the individual actors and concludes.

I The features presented here are standard in textbook models as AS-AD (McCallum 1989: chapter 5, or Romer 1996: chapter 5) or the New Classical Model (Lucas 1972 and 1973). 


\section{Macroeconomic Responsibilities in Neoclassical Theory}

In neoclassical theory with perfect competition, output and employment are determined in the labour market in which individuals offer their labour up to the point at which their marginal disutility to work equals the real wage paid. At the same time, firms hire until labour's marginal product equals the real wage they have to pay. While a nominal wage is contracted in the labour market, it is the real wage that counts for production and labour supply decisions. This real wage is determined by the nominal wage and the price level which is set via a quantity equation by the central bank.

As individuals anticipate the central bank's policy stance and at the same time want to achieve a certain real wage for their work, they will adjust their nominal wage demands in a way that after the central bank's monetary policy actions the real wage remains unaltered. Only if they are surprised by the central bank's monetary policy, the unanticipated change in prices will transitorily alter real wages and consequently employment and output. However, it is not possible to exploit this mechanism for macroeconomic policy in a systematic way as individuals will rationally anticipate the central bank's actions.

Thus, inflating the economy does not yield long-lasting improvements in output or employment. In such a world, all remaining unemployment is voluntary or due to some institutional labour market features which keep nominal wages from adjusting downwards so that real wages fall and employment increases. One possible barrier to downwardly flexible wages and thus full employment could be unions which collectively bargain for wages, using their market power to achieve a real wage which is above a level compatible with full employment (Burda/ Wyplosz 1997: 150).

For monetary policy, this view of the world yields the conclusion that all a central bank should do is maintain a low and stable rate of inflation. As monetary policy leaves output and employment unaffected in both the medium and the long run, the central bank does not have any responsibility for unemployment or growth. Moreover, as politicians might be inclined to inflate to reap short-term gains from a temporarily lower rate of unemployment, control over monetary policy should be given to some independent central bank, preferably headed by a central banker who has a strong distaste for inflation (Rogoff I985). Since economic agents rationally expect the anti-inflationary stance of such an independent central bank, they adjust their inflation expectations downwards. Reducing inflation thus comes without any real costs, an independent central bank just yields more macroeconomic stability quasi as a "free lunch" (Grilli et al. I99I).

Adding some wage or price stickiness to this model renders possible that demand falls short of supply in the short term, thus causing transitional unemployment (e.g., Fischer I977, Taylor 1980). In those settings stabilisation policy by the central bank can be beneficial as the central bank can dampen short-term fluctuations.

However, in the long run the central bank cannot influence output or employment. Moreover, while there might be some preference by the society for the central bank to stabilise output in the short term, there is no necessity to do so. In the AS-AD-world as well as in the New Classical world or in extensions of the world of monopolistic competition 
(Blanchard/ Kiyotaki 1987), the economy will find back to full employment even when a passive central bank does not react to a negative demand shock: in these models, aggregate demand is a function of real money balances. Any shortfall of aggregate demand below aggregate supply leads to a fall in prices, which in turn increases real money balances. These increased real balances push up aggregate demand until equilibrium is reached again. While a deviation of aggregate demand from aggregate (equilibrium) supply is possible in the short term, it is not possible in the long term. ${ }^{2}$

When these models are extended by monopoly unions, unions have responsibility for unemployment. Their monopoly power tends to push wages above the full employment wage. By restraining wage demands, they can lower real wages, thus making employing an additional unit of labour at the margin more profitable, which in turn leads to higher employment. For the unions, there is thus a pay-off between high real wages and high employment. Consequently, it is the central bank which is responsible for price stability while the unions can be blamed if full employment is not reached.

The question how unions and the central bank interact given this distribution of responsibilities is further elaborated in recent contributions following the seminal work of Hall / Franzese (1998). Soskice/ Iversen (2000) and Coricelli et al. (2000) (SICCD thereafter) construct a model of monopolistic competition in which unions consciously make use of the possibility to trade wage restraint for higher employment. Aggregate demand is again a function of real money balances in those models. When faced with a non-accommodating central bank which does not try to influence employment, but keeps the nominal money supply at a given level, the unions can increase aggregate demand and thus employment by wage restraint. With lower wage demands, ${ }^{3}$ the price level falls, thus increasing real money balances. These higher real money balances translate into higher aggregate demand, output and employment.

\section{Dropping Real Balances from the Demand Function}

Central to the idea of an economy returning to equilibrium by itself as well as the notion of unions being able to increase aggregate demand by their wage demands is the assumption of aggregate demand being a function of real money balances. However, while the assumption of a relevant real balance effect is element of many textbook macroeconomic models, ${ }^{4}$

2 In this respect, newer models like Clarida et al. (1999) or Romer (1999 and 2000) differ from the older textbook models. As in these models real balance effects do not exist, the central bank has to be actively stabilising the economy in order to keep it from spiralling into accelerating inflation or deflation.

3 In fact, Soskice / Iversen (2000) build closely on Blanchard / Kiyotaki (1987) so that workers also produce. Therefore, their products' sales price equals their wage. Coricelli et al. (2000) model firms which maximise their profits and hire workers according to their maximisation result.

$4 \quad$ It should be noted that some very recent contributions such as Romer (1999), Romer (2000) or Clarida et al. (1999) completely drop the real balance effect as mechanism of monetary policy transmission (see below). 
its theoretical foundations are highly problematic. ${ }^{5}$ In standard models such as AS-AD or the New Classical approaches, real balances influence aggregate demand via two channels: first, as real balances are part of the private sector's net wealth, and consumption is a function of net wealth, consumption increases with increasing real balances (Pigou effect). Second, when individuals suddenly face higher real balances than they would hold in equilibrium, they start reallocating their assets. They will start buying bonds against their money holdings, which will drive down the interest rate. Lower interest rates then translate into higher investment demand (Keynes effect).

Thus for the Pigou effect to work, money needs to be net wealth for the private sector. For the Keynes effect to work, the money supply has to be set exogenously. Both assumptions are questionable on institutional and theoretical grounds. In the Euro area, high-powered money comes into circulation when banks grant credit to their clients and have thus to borrow money from the European Central Bank (ECB). An increased money stock always comes with equivalently increased liability of some private party. In consequence, with changes in the price level the net wealth position of the private sector remains unchanged: as the money stock is backed by the same amount of private sector liabilities to the central bank, private sector debt increases at the same time and by the same amount as does gross private sector wealth. Thus, private net wealth does not change with changes in the price level. ${ }^{6}$

A counter-argument could be that in some advanced economies such as the United States, the central bank purchases government bonds in its conduct of monetary policy. ${ }^{7}$ In this case, a large part of the circulating money stock is thus backed by government debt in the central bank's balance sheet. One could thus argue that a fall in the price level would increase the real value of the private sector's money holdings without increasing the private sector's liabilities. But even for money backed by government debt it is questionable if a Pigou effect can be at work. If Ricardian equivalence holds and thus the private sector does not get richer when the stock of government debt rises, also a fall in the price level would not increase net wealth: the real value of government debt outstanding would rise exactly by the same amount the real value of money in the individuals' portfolios increases. The net effect would be zero.

The fact that money comes into existence when commercial banks borrow from the central bank also calls into question the notion of a Keynes effect when prices change. In standard textbook models, the real value of money available for credit in the economy increases with a falling price level. However, as in reality the money stock is not exogenously fixed, and money is created as a reflex to credit demand, one can assume that the money stock moves proportionally with the price level: as households and firms need credit in

5 This section's arguments are in line with much of Post-Keynesian work on endogenous money, e.g. Moore (1989) or Wray (1990). For more on the discussion of the possible relevance of real balance effects, see Dullien (2004a: chapter 3).

6 Of course, one could argue that there is a liquidity effect due to different maturities of money and debts. However, as Dullien (2004a: 60 ff.) shows, this effect can only be expected to be extremely marginal and will thus have no real effects on economic activity.

$7 \quad$ The ECB usually does not buy any debt securities on a definite basis. 
order to conduct real investment or to consume more in real terms, they will demand accordingly less credit when prices are falling (Betz 200I: $58 \mathrm{ff}$.). For those firms and households who are credit-constrained, the banking sector will change the nominal credit volume with a changing price level. With all prices decreasing, also future nominal household or firm earnings will decrease. The banks will lower their nominal credit ceilings. The opposite is true for rising prices. As expected future nominal cash-flows increase, credit ceilings are raised. As neither banks nor firms live under money illusion, the real credit constraint does not change when the price level changes.

These problems with real balance effects have led to a recent trend away from models which rely on the real balance effect as a mechanism of monetary policy transmission. Romer (1999 and 2000) as well as modern literature on the efficiency of monetary policy rules building on New Keynesian models as presented in Clarida et al. (1999) use the short-term (real) interest rate as the way monetary policy affects the real economy and drop real balances completely from the picture. This path is followed by the model presented in the next section.

\section{A Baseline Model Without Real Balances}

The model used in this paper builds on the formulation of Dixit / Stiglitz (1977: chapter 8), Blanchard / Fischer (1989) and Blanchard/ Kiyotaki (1987) as also used by Soskice/ Iversen (2000) and Coricelli et al. (2000). Especially the derivation of the demand function a single firm faces for its products remains essentially the same as in Blanchard/Fischer (1989: chapter 8) or in the predecessing work of Dixit/Stiglitz (1977). Instead of having worker-producers who directly provide the economy with their products as in the early Blanchard contributions, a profit-maximising firm is modelled following Coricelli et al. (2000). Consequently, there is not only a price for the single product sold (which the workerproducer would then receive), but also an explicit nominal wage paid to workers employed by the single firms.

What is different from these standard models, however, is the introduction of a capital stock and a different formulation of aggregate demand. While in the standard models of monopolistic competition the only input entering the production function is labour, the single firm in my model chooses both capital and labour employed. Moreover, while in the original formulations aggregate demand depends on real balances $M / P$, the model presented here does not incorporate this chain of causation. Monetary policy thus does not work by changing the money supply $M$, but by setting the rate of interest. This rate of interest then leads firms to change their decisions about capital input, which leads to a higher capital stock on the supply side and to higher investment demand on the demand side. ${ }^{8}$

8 In equilibrium, investment demand changes with the capital stock as more replacement investment is necessary. In disequilibrium, changes in the equilibrium capital stock lead to changes in net investment. 
The economy is composed of $n$ monopolistically competitive firms, each producing a good $i$ given a simple Cobb-Douglas-production function. Labour $N_{i}$ and capital $K_{i}$ are the two input factors of firm $i$. In addition, some technological level $A$ also enters the production function as Hicks-neutral technological progress:

$$
y_{i}=A N_{i}^{\alpha} K_{i}^{1-\alpha}, 0<\alpha<1 .
$$

The firms' demand functions are derived from maximising an individual consumer's CES utility function. ${ }^{9}$ When assuming that the same preference for variety holds for all demand components (consumption, government consumption), each firm is thus confronted with a (real) demand function $y_{i}^{D}$ for its output ${ }^{\mathrm{IO}}$ being a function of the price of its good $P_{i}$, the price level $P$, the number of goods $n$ which are produced and enter the individuals' CES utility function, the (absolute value of the) elasticity of demand facing the individual firm $\eta$ (which is also the constant elasticity of substitution in the CES utility function) ${ }^{\mathrm{II}}$ and the aggregate nominal demand $Y^{D}$ (which will be specified more in detail later on):

$$
y_{i}^{D}=\frac{1}{n}\left(\frac{P_{i}}{P}\right)^{-\eta} \frac{Y^{D}}{P} .
$$

As standard in models of monopolistic competition, for a stable equilibrium to exist, $\eta>1$ must hold (Blanchard/ Fischer 1989: 377). The aggregate price level is given by:

$$
P=\left(\sum_{j=1}^{n} \frac{1}{n} P_{j}^{(1-\eta)}\right)^{\frac{1}{1-\eta}}=\left(\frac{1}{n} \sum_{j=1}^{n} P_{j}^{(1-\eta)}\right)^{\frac{1}{1-\eta}} .
$$

For the long-run equilibrium, each firm chooses its capital stock and its employment per unit of output so that unit costs $u c_{i}$ are minimised given the capital costs (interest rate $i^{K}$ it has to pay on the nominal capital employed ${ }^{12}$ plus the technical rate of depreciation $\delta^{13}$ ) and the wage $W_{i}$ the single firm has to pay: ${ }^{14}$

$$
\min _{K_{i}, N_{i}} u c_{i}=W_{i}\left(\frac{N_{i}}{y_{i}}\right)+P\left(\delta+i^{K}\right)\left(\frac{K_{i}}{y_{i}}\right) .
$$

9 As Heijdra/van der Ploeg (2002: 362 ff.) show, the distribution of income on different types of goods can be separated from the question how much an individual consumes. Thus this approach is compatible both with the assumption of a Keynesian as well as a classical consumption function.

Io Blanchard / Fischer (1989: 376 ff.) show how to derive this demand function from the consumers' maximisation decisions. See also Dixit/ Stiglitz (1977) or Blanchard/Kiyotaki (1987). As the exact functional form does not add to this paper, it is omitted here.

II Note that all firms are faced with the same elasticity of demand $\eta$.

I2 Alternatively, this interest rate might represent the opportunity costs for not investing in some financial market asset.

I3 Again, for making the system solvable, the rate of depreciation is assumed to be constant.

I4 Note that we have to multiply the real capital stock $K_{i}$ by the price level $P$ in order to get the nominal capital stock and to be able to add nominal capital costs to nominal wage costs. 
For simplicity, it is assumed that the central bank can set the interest rate $i^{K}$. Using (I) as a constraint, (4) yields capital and labour employed in equilibrium per unit of output produced: ${ }^{\text {is }}$

$$
\begin{gathered}
\frac{K_{i}^{*}}{y_{i}}=\frac{1}{A}\left(\frac{W_{i}}{P}\right)^{\alpha} \frac{(1-\alpha)^{\alpha}}{\left(\delta+i^{K}\right)^{\alpha} \alpha^{\alpha}}, \\
\frac{N_{i}^{*}}{y_{i}}=\frac{1}{A}\left(\frac{P}{W_{i}}\right)^{1-\alpha} \frac{\left(\delta+i^{K}\right)^{1-\alpha} \alpha^{1-\alpha}}{(1-\alpha)^{1-\alpha}} .
\end{gathered}
$$

Equilibrium unit costs $u c_{i}^{*}$ are given by:

$$
u c_{i}^{*}=W_{i}\left(\frac{N_{i}^{*}}{y_{i}}\right)+P\left(\delta+i^{K}\right)\left(\frac{K_{i}^{*}}{y_{i}}\right)=\frac{1}{A} P^{1-\alpha} W_{i}^{\alpha} \frac{(\delta+i)^{1-\alpha}}{\alpha^{\alpha}(1-\alpha)^{1-\alpha}} .
$$

Given the unit costs in this cost minimum equilibrium, the single firm in a second stage maximises its profits $\Pi_{i}$ by choosing the price for its product $P_{i}$ given the general price level and the demand function it faces. The firm then produces as much as is demanded for the price it asks:

$$
\begin{aligned}
& \max _{P_{i}} \Pi_{i}=\left[P_{i}-u c_{i}^{*}\right] y_{i}^{D} \\
& =\left[P_{i}-u c_{i}^{*}\right] \frac{1}{n}\left(\frac{P_{i}}{P}\right)^{-\eta} \frac{Y^{D}}{P} .
\end{aligned}
$$

Maximising yields:

$$
P_{i}=\frac{-\eta}{(1-\eta)} u c_{i}^{*}
$$

When all firms are faced with the same wage level $W$ and the same technological conditions (expressed in a similar total factor productivity $A$ and similar share of labour in the Cobb-Douglas production function $\alpha$ among all firms), all prices $P_{i}$ are necessarily identical. We can thus solve for all prices and the general equilibrium price level $P^{*}$ by substituting (6) and (5) as unit costs (7) into (IO): ${ }^{16}$

$$
P^{*}=P_{1}=\ldots=P_{n}=A^{-\frac{1}{\alpha}}\left(\frac{-\eta}{1-\eta}\right)^{\frac{1}{\alpha}} \frac{\left(\delta+i^{K}\right)^{\frac{1-\alpha}{\alpha}}}{\alpha(1-\alpha)^{\frac{1-\alpha}{\alpha}}} W .
$$

I5 Details about the mathematics will be made available on the author's website at the moment of publication of this article.

I6 This price level can be interpreted in the tradition of Keynes (I930), Riese (I986) or Collignon (1999 and 2002) as an interest rate-related mark-up over wage costs. 
Thus, the price level is proportional to the nominal wage level. The assumption of a uniform wage level is not as restrictive as it seems at first sight: a uniform wage level would either be the result of a monopoly trade union bargaining for wages in the whole economy or of a completely flexible (that is atomistic and friction-free) labour market in which free movement of labour would guarantee that wages in a single firm do not deviate from the market wage $W .{ }^{17}$

The real wage per unit of labour employed is given by:

$$
\varpi=\frac{W}{P}=\alpha A^{\frac{1}{\alpha}}\left(\frac{1-\eta}{-\eta}\right)^{\frac{1}{\alpha}} \frac{(1-\alpha)^{\frac{1-\alpha}{\alpha}}}{\left(\delta+i^{K}\right)^{\frac{1-\alpha}{\alpha}}} .
$$

Real profits per unit of production are given by:

$$
\frac{\Pi^{*}}{P y}=1-\frac{1-\eta}{-\eta}\left(\alpha+\delta \frac{1-\alpha}{\delta+i^{K}}\right) .
$$

Thus, the real wage and real profits per unit become independent from the nominal wage. The argument behind this seemingly startling result is that firms set their prices as a markup over nominal costs as derived from their profit-maximising decision in goods markets with imperfect competition. A fall in the nominal wage level lowers costs for all companies in the market. Thus, each firm is not only faced with lower costs of production, but also with competitors who are able to lower their prices. Consequently, they will cut their prices until they have adjusted their mark-up to the equilibrium value at which real wages and real profits per unit will not have changed.

With all prices being identical, (2) simplifies to:

$$
y_{i}^{D}=\frac{1}{n} \frac{Y^{D}}{P} .
$$

Equilibrium capital $K_{i}^{*}$ and labour $N_{i}^{*}$ employed in each firm is given by multiplying capital (5) and labour (6) per unit of output by the firm's actual production (I4):

$$
\begin{gathered}
K_{i}^{*}=\frac{1}{n A}\left(\frac{W}{P}\right)^{\alpha} \frac{(1-\alpha)^{\alpha}}{\left(\delta+i^{K}\right)^{\alpha} \alpha^{\alpha}} \cdot \frac{Y^{D}}{P}, \\
N_{i}^{*}=\frac{1}{n A}\left(\frac{P}{W}\right)^{1-\alpha} \frac{\left(\delta+i^{K}\right)^{1-\alpha} \alpha^{1-\alpha}}{(1-\alpha)^{1-\alpha}} \frac{Y^{D}}{P} .
\end{gathered}
$$

At first sight, these results are not very startling yet: as standard also in neoclassical models, the higher real wages, the more capital and the less labour are employed per unit of out-

I7 It should be added that this model abstracts from different kinds of labour or different qualifications among workers. 
put. The higher the rate of interest, the less capital and the more labour are employed per unit of output. The results also embody Keynes' (1936: 135) notion of marginal efficiency of capital: the firm employs an additional unit of capital if the proceeds from selling the additional production are at least equal to the cost of employing the additional unit of capital. ${ }^{18}$

However, when we remember that the price level is proportional to the wage level (II), we see that the choice of the individual capital stock and employment becomes independent from the nominal wage.

\section{I Macroeconomic Aggregates}

Aggregating the firms' capital stocks and employment and substituting (II), the aggregate equilibrium capital stock $K^{*}$ and aggregate equilibrium employment level $N^{*}$ are thus:

$$
\begin{gathered}
K^{*}=\left(\frac{1-\eta}{-\eta}\right) \frac{1-\alpha}{\delta+i^{K}} \frac{Y^{D}}{P}, \\
N^{*}=\left(\frac{-\eta}{1-\eta}\right)^{\frac{1-\alpha}{\alpha}} \frac{\left(\delta+i^{K}\right)^{\frac{1-\alpha}{\alpha}}}{A^{\frac{1}{\alpha}}(1-\alpha)^{\frac{1-\alpha}{\alpha}}} \frac{Y^{D}}{P} .
\end{gathered}
$$

So far, this result also holds when we use an aggregate demand function with real money supply $M / P$ as an argument. In this case (and with an exogenously set $M$ ), unions could actually increase employment by lowering their wage demands. Lower wages would translate into lower prices via (II) and higher real balances. As higher real balances then would lead to higher demand, employment and output would be higher than before. The direct link proclaimed in the models of Soskice and Iversen (2000) and Coricelli et al. (2000) from lower nominal wage demands to higher output when the central bank is not active would still be intact.

However, as I have argued above, a significant real balance effect cannot be expected to work in the real world. Instead, one should include income flows from wages and profits as well as investments derived from the firms' individual decisions into the aggregate demand function. The part of consumption which depends on income is modelled as a constant share $c$ of the wage bill. ${ }^{19}$ Such a consumption function could be interpreted in two ways. First, it could of course be interpreted as a standard Keynesian demand func-

I8 Note that the proceeds from one additional unit are less than the sales price, as for a firm facing monopolistic competition the supply of an unit of production drives down not only the marginal price it gets for its goods, but also the price for all other units produced.

I9 The basic results do not rely on the assumption that in this model all profits are saved and only part of the wage bill is consumed. One could easily solve the model for the classical saving hypothesis, thus setting $c$ to I. In this case, the multipliers would just get a little larger. Just the same, it is straightforward to assume that also profits are to a certain extent consumed. As is shown on the author's website, the multiplier in this case gets a little more complicated, but output and employment still are not functions of the nominal wage level. 
tion. Second, it could be interpreted as a special case of the permanent income hypothesis: If - as in this model - there is no natural tendency to any specific employment equilibrium, one could argue that the individuals assume any actual income as a likely permanent income. In this case actual and permanent income would be the same, and consumption would be a share of permanent income. ${ }^{20}$

Investment demand is derived from the fact that firms maximise their profits by varying labour and capital input and thus production of their product. Given the demand conditions, firms will aim at some equilibrium capital stock. For given demand conditions and given nominal wages, firms will employ more capital the lower the interest rate $i^{K}$. As soon as they have attained this capital stock, they will only invest the exact amount necessary to replace depleted capital stock. In equilibrium, investment demand is thus exactly equal to the depreciation of the capital stock employed. ${ }^{21}$ In situations in which the equilibrium is not yet reached, there is also some net investment bridging a share $\xi$ between the actual capital stock $K$ and the desired equilibrium capital stock $K^{*}$. ${ }^{22}$ Real capital demand is thus a function of the interest rate $i^{K}$ which is set by the central bank. As capital is a real variable, to deduct nominal demand, we have to multiply investment demand by the price level $P .{ }^{23}$ Finally, we will allow for one further autonomous ${ }^{24}$ real demand component $y_{0}^{D}$, i.e. autonomous consumption demand:

$$
Y^{D}=c N^{*} W+\xi P\left(K^{*}-K\right)+\delta P K+P y_{0}^{D} .
$$

For the equilibrium case $K=K^{*}$, this simplifies to:

$$
Y^{D}=c N^{*} W+\delta P K^{*}+P y_{0}^{D} .
$$

Substituting (I9) into (I8) yields an equilibrium aggregate real output for the whole economy as well as an equilibrium aggregate employment being independent from the nominal wage level:

$$
y^{*}=\frac{\eta}{\eta+(1-\eta)\left(c \alpha+\frac{\delta(1-\alpha)}{\left(\delta+i^{K}\right)}\right)} y_{0}^{D},
$$

20 This would fit well with the empirical fact that many macroeconomic variables including output and consumption are often found to behave rather like a random walk than like a stationary variable as has been shown by Nelson / Plosser (1982).

2I This model abstracts from steady state growth and thus from autonomous investment.

22 The fact that firms do not invest at once as to meet their desired capital stock can be explained either by technical factors limiting the amount of capital adjustment possible in one period or by adjustment costs (Romer 1996: $348 \mathrm{ff}$.).

23 Remember that in this model it is assumed that one unit of investment has the same composition of the single firm's products as one unit of consumption.

24 Not being a function of current income. 


$$
N^{*}=\left(\frac{-\eta}{1-\eta}\right)^{\frac{1-\alpha}{\alpha}} \frac{-\eta\left(\delta+i^{K}\right)^{\frac{1-\alpha}{\alpha}}}{A^{\frac{1}{\alpha}}(1-\alpha)^{\frac{1-\alpha}{\alpha}}\left[-\eta+(\eta-1)\left(c \alpha+\frac{\delta(1-\alpha)}{\left(\delta+i^{K}\right)}\right)\right]} y_{0}^{D} .
$$

Both output and employment are proportional to autonomous demand. However, the respective multipliers differ both in form and in the way they depend on other parameters. While output clearly increases with lower interest rates, the employment effect of a change in interest rates is ambiguous due to the fact that a substitution between capital and labour takes place depending on the level of nominal interest rates $i^{K}$. This mechanism will be covered more in detail in section 4.2 .

\subsection{Interpretation}

These results are quite interesting. First, it has to be noted that the price level (II) is proportional to the wage level. In addition, the price level is a positive function in the nominal interest rate. The higher the interest rate ceteris paribus, the higher are also prices. This conclusion might at first be startling (as higher interest rates are used by central banks to fight inflation), but is only a result of the fact that higher interest rates in this model translate into higher capital costs for the single firm. ${ }^{25}$ Additionally, the higher the elasticity of substitution between different products, the lower the price level. As the elasticity of substitution can be interpreted as the inverse degree of the firms' monopoly power (Blanchard/ Giavazzi 2000), this is easily explainable: the higher the degree of monopoly power, the higher are monopoly profits and the higher is thus the mark-up over wage and capital costs.

With prices proportional to nominal wages, real wages are independent from nominal wages. As the firms' maximisation leads to price setting as a mark-up over nominal costs, variations in the nominal wage do not change the real wage level. Instead, real wages are a function of the technological parameters $A, \delta$ and $\alpha$, the monopoly power $\eta$ and the interest rate. For the real wage and the profit per unit of production, the influence is as expected: a higher weight of labour in the production function increases real wages and decreases real profits per unit of production. Higher interest rates translate into lower real wages and higher unit profits.

With the real wage being independent from nominal wages, output and employment are not functions of the nominal wage level. Instead, both output and employment are only functions of the structural parameters of the production function, the technological progress and the elasticity of substitution of the single goods (which can be interpreted as some measure of monopoly power), the interest rate, the rate of depreciation and autonomous demand. Employment is proportional to output and, in addition to being a function of output, itself a function of the degree of monopolisation as well as the capital costs. The higher the capital costs, the more labour is used to produce a single unit of output and

25 This is much in line with the recent findings of Barth / Ramey (200I) who proclaim a cost channel of monetary policy transmission. 
the less capital is used. Thus, with higher interest rates, production becomes more labourintensive. In a similar way, the higher the degree of monopoly power, the less capital-intensive is the production which takes place. Consequently, employment per unit produced is a positive function of $\eta$. However, this increased employment per unit produced stands against the fact that overall output is reduced when interest rates are higher as well as with a higher degree of monopoly power. Higher interest rates translate into a lower aggregate capital stock and thus lower investment demand. A higher degree of monopolisation lowers real wages and thus the workers' consumption demand.

In the world of this article's model, unemployment could persist even if there was a completely competitive labour market. Even if nominal wages started to fall as soon as employment $N^{*}$ was below some full employment level $\bar{N}$, this would not lead to an increase in employment or output: the fall in nominal wages would lead to a proportional fall of the firms' costs as well as their competitors' costs. Given the assumption of imperfect competition, firms would try to hold their mark-up constant, thus leading to a proportional fall in prices. All real variables would remain unaltered. The dynamics of nominal wages with different labour market set-ups are analysed in more detail in section 5 .

This article's model is thus in strong contrast to the neoclassical synthesis usually taught in undergraduate courses as well as to the SICCD models mentioned earlier: as the price level in neoclassical textbook models is determined by a quantity equation (in contrast to the microeconomically founded price setting of this article's model), a variation of the nominal wage also leads to variation in the real wage in the same direction, thus causing changes in output and employment. In the SICCD world, a different mechanism leads to higher employment when nominal wages fall: while prices in Soskice/ Iversen (2000) would adjust to a fall in nominal wages very much the same way as in this paper's model, a change in output and employment is only brought about by a consequent increase in real balances. With constant nominal money holdings the fall in prices leads to an increase in real balances, thus inducing higher aggregate demand. As this article's model does not include real balances, this adjustment mechanism is ruled out.

Moreover, in our model, a higher degree of the firms' monopoly power (expressed in a lower elasticity of substitution $\eta$ ) decreases real wages and aggregate output. ${ }^{26}$ The relationship between $\eta$ and the real wage is straightforward: as a lower $\eta$ means a higher mark-up over nominal wages and nominal capital costs, it also translates into workers receiving a smaller share of output. The relationship between output and the degree of monopolisation is a little more complicated: as a higher price level also increases the price for capital goods, it lowers the capital stock employed and consequently the equilibrium demand for investment goods. Consequently, less goods are both produced and demanded, leading to a lower output.

From this result interesting policy conclusions can be drawn: if product market deregulations lead to a fall in the firms' monopoly power, they increase output and real wages. While all attempts to increase output by lowering real wages via a cut in nominal wages will fail in this model, measures to increase $\eta$ might prove highly successful. Interestingly, 
in this case, higher real wages coincide with higher output. However, this is not a result of causality: increases in nominal wages in order to get higher real wages would be as futile as attempts to cut real wages by cutting nominal wages. Instead, a lower mark-up increases both investment and real wages.

Finally, as the interest rate influences the amount of capital employed, both supply and demand of goods rise with lower interest rates: with a larger capital stock per worker, productivity and output per capita are higher. At the same time, a higher capital stock needs higher equilibrium (gross) investments to sustain, thus increasing aggregate demand. Lower interest rates thus lead to higher output in this setting.

The fact that some kind of substitution between labour and capital takes place at the firm level leads to somewhat ambiguous results as to how changes in the interest rate translate into changes in employment, because two effects with different signs appear: a substitution effect, lowering unemployment, and a demand effect, increasing unemployment. On the one hand, lower interest rates lead to a substitution of labour against capital on the firm level. At the same time, demand increases as real wages increase and the equilibrium capital stock per unit of output gets bigger, thus leading to a higher investment demand. At low interest rates, the demand effect is larger than the substitution effect. At very high interest rates, on the other hand, the capital stock is already very low. A variation here does not bring much variation in the demand of investment goods to replace depreciated capital. Here, the substitution effect is bigger than the income effect, lower interest rates here would lead to lower employment.

Differentiating (22) with respect to the interest rate $i^{K}$ and solving shows that the employment effect of lower interest rates is positive as long as

$$
i^{K}<\frac{\delta((\eta-1) c \alpha-1)}{\eta-\eta c \alpha+c \alpha}
$$

holds. Unfortunately, the interpretation of this term is not trivial. Partial differentiation shows that the right hand term is a positive function in $\alpha, c, \eta$ and $\delta$. This can be explained as with an increase in any of these parameters, the amount by which an additional unit of capital employed increases aggregate demand increases: with less monopoly power, real wages are higher, thus consumption increases more strongly when employment raises. The same is valid for $\alpha$ : with a higher weight of labour in the production function, the effect of an increase in aggregate demand on the real wage bill and thus on aggregate consumption is higher. For $c$ and $\delta$ the argument is that higher parameter values lead to a higher increase in aggregate demand for any given increase in the capital stock.

However, for a wide range of plausible parameter values, the interest rates observed in the real world are clearly in the range in which an increase in interest rates would lead to a fall in employment: assuming that $\eta$ is in the range of $20, \alpha$ around $0.7,{ }^{27} \delta$ around

27 This combination between $\alpha$ and $\eta$ would mean that although the weight of labour in the production function is 0.7 , an often assumed value (Romer 1996: 22), labour would only earn roughly 65 percent of the production. 
0.2, interest rate increases up to roughly 20 percent would lead to a decrease in equilibrium employment. For the rest of this paper, I will thus assume that the parameters are in a range such that a cut in interest rates actually also leads to an increase in employment.

The conclusion that employment and output are independent from the nominal wage level would explain why unit labour cost increases below inflation and target inflation in Italy, France or Germany during parts of the I990s did not lead to a significant increase in employment. In a closed economy as depicted in this model, cutting nominal wages does not create employment as aggregate demand falls with falling costs and firms are not able to demand the same prices for their products as they used to before the change in wages.

This is a conclusion completely at odds with macroeconomic textbook models: while it is usually not disputed that a cut in wages also diminishes workers' consumption demand, real money balances in standard models do the trick to increase aggregate demand when wages are falling. Lower wages and prices lead then to an increase in private wealth which translates either in higher consumption demand (via the Pigou effect) or into higher investment demand (via the Keynes effect).

In the model presented here, real balance effects do not exist. A cut in nominal wages thus dampens directly and proportionally nominal demand. As all firms are faced with both lower costs and a shifted nominal demand curve, they cut their prices until their profit maximum is reached. In this new equilibrium, real variables have not changed. Only prices have adjusted.

\section{The Labour Market and Wage Dynamics}

So far, we have not analysed wage setting in detail. In the section above, it was just stated that both in a highly competitive labour market and in a labour market with centralised wage setting, the wage level $W$ would be uniform across firms. However, as we know from equation (II), even though the nominal wage level $W$ does not influence output and employment, nominal wage dynamics are central for understanding inflation dynamics. This section will therefore try to explain how wages develop in a world without the real balance effect. To this end, I first take a look at a situation in which a perfect neoclassical labour market exists. In a second step, I show how a setting with a single large, strategically acting wage setter changes the picture.

\section{I Theoretical Considerations: A Neoclassical Labour Market}

In a standard neoclassical or textbook atomistic labour market, there is a natural rate of unemployment which is equivalent to the non-accelerating inflation rate of unemployment (NAIRU). Whenever actual unemployment rises above the NAIRU, labour supply exceeds labour demand. Consequently, nominal wage increases start to moderate. When actual unemployment falls below the NAIRU, excess demand for labour triggers rising nominal wage increases (Romer I996: 225 ff., or Blanchard/ Fischer 1989: 544). Figure I (p. 294) illustrates 
this concept. Unemployment below $U_{\text {NAIRU }}$ leads to accelerating wage increases, unemployment above $U_{\text {NAIRU }}$ to decelerating wage increases. ${ }^{28}$

Figure I: Wage Increases and Unemployment in an Atomistic Labour Market

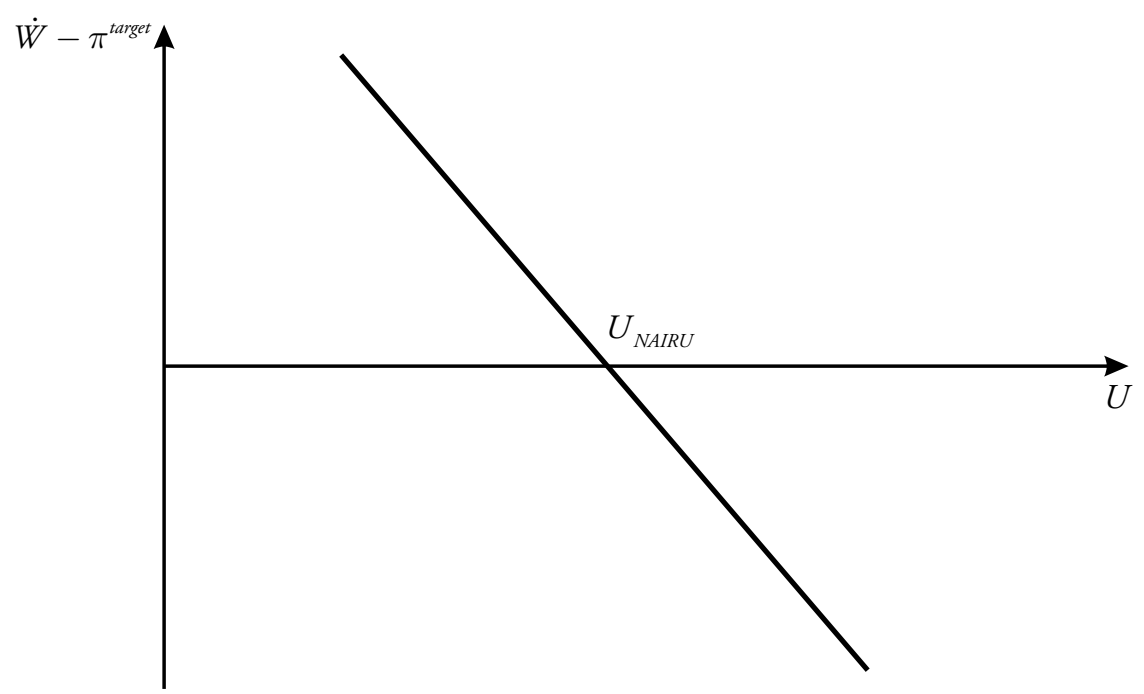

Adding such a labour market to the model presented in this paper would not change any of the conclusions from the last section. However, such a labour market would provide significant instability to the system. As falling nominal wages do not help to bring unemployment back to $U_{N A I R U}$, any shortfall in demand would finally turn into a deflationary spiral. Such a system would not show any tendency to stabilise itself. Instead, monetary and fiscal policy would have to take on an active role and keep aggregate demand exactly at the point where unemployment equals the NAIRU. ${ }^{29}$

It is interesting to note that in such a system increased rigidities in the labour market can help to stabilise the system. The quicker the overall wage level reacts to deviations of aggregate demand from the level at which unemployment equals the NAIRU, the easier the system might experience high inflation or deflation. However, the speed at which wages adjust depends critically on labour market rigidities: the less frequent for example wage readjustments, the smaller the danger for the system to spiral into deflation or inflation.

28 I am well aware of all the methodological problems of the NAIRU concept as described in Galbraith (1997) and other contributions of the Winter 1997 issue of the Journal of Economic Perspectives or which have recently been voiced by Beyer/Farmer (2002). See Carlin/Soskice (1990) for the differences between NAIRU and Natural Rate concepts.

29 In reduced form models such as in Clarida et al. (1999), monetary policy actually takes up this role as embodied in the monetary policy reaction function. 


\subsection{A Monopoly Union}

The picture changes completely when a monopoly trade union is setting wages for the whole economy. In standard theory, there would still be a single point NAIRU with a monopoly union. By pushing for higher nominal wages, the union could influence real wages and unemployment (Burda/ Wyplosz 1997: 150). The case why a union cares about its members' real wages is clear-cut. Real wages translate into union members' higher personal incomes and thus higher utility. There are several reasons why a union might also care about unemployment. First, in countries with developed unemployment or welfare systems, there exist costs associated with higher unemployment. If these costs are financed either by general or payroll taxes, unions have an interest in keeping them low. Second, as Blanchard/ Summers (1987) note, a fall in employment might also lead to a fall in union membership. Union leaders should fear such a development as they would lose power and revenue. Third, higher unemployment increases the union members' risk to get unemployed. This risk lowers their respective utility and they can be expected to push their leaders into caring about unemployment as well.

A rational monopoly union would thus take into account if its wage demands increase unemployment and choose an optimum level of unemployment and real wages. According to standard theory, the union would use its monopoly power to push for somewhat higher wages than in the atomistic labour market case, accepting unemployment above the NAIRU in an atomistic labour market. However, if a shock to aggregate demand leads to unemployment rising above that threshold, it would be rational for the union to take back its wage demands to get unemployment back to that optimum. If increased aggregate demand would push unemployment below that point, the union would increase wage demands to find its optimum.

In this paper's model, however, the wage level set by centralised wage bargaining $W$ does not influence employment or the real wage. Different from the argumentation in the models of Soskice/Iversen (2000) and Coricelli et al. (2000), there is thus no reason for unions restraining their wage demands in order to increase employment. At the same time, there is no reason for unions to push for generally higher nominal wages to improve their real wage position. Thus, the monopoly union should be completely indifferent to the nominal wage level. As long as wage bargaining structures (and thus the union's monopoly to bargain for wages) remain stable, there are multiple equilibria of stable wage inflation and unemployment: price stability is thus compatible with a wide range of unemployment.

This does not necessarily mean that stable prices are compatible with every level of unemployment. From a certain unemployment rate downwards, there might be real shortages in the labour market. A single firm looking for workers might just offer them higher wages or non-monetary benefits above centrally bargained wages in order to lure them onto its payroll. The rate of wage increases would accelerate.

Similarly, from a certain rate of unemployment upwards, it could be hard to uphold union monopoly power. A small union bargaining wages for a single firm or even a small 
group of firms is able to increase employment in its constituency at the expense of the rest of the economy by cutting its nominal (and given that the price level is determined by the average wage its real) wage. If unemployment gets too pressing, there is the danger that unemployed try to price themselves back into the market via this mechanism. Monopolised wage bargaining would break down. Thus, from a certain point of unemployment upwards, wage increases would decelerate.

Figure 2: Wage Increases and Unemployment in a World With a Large Wage Setter

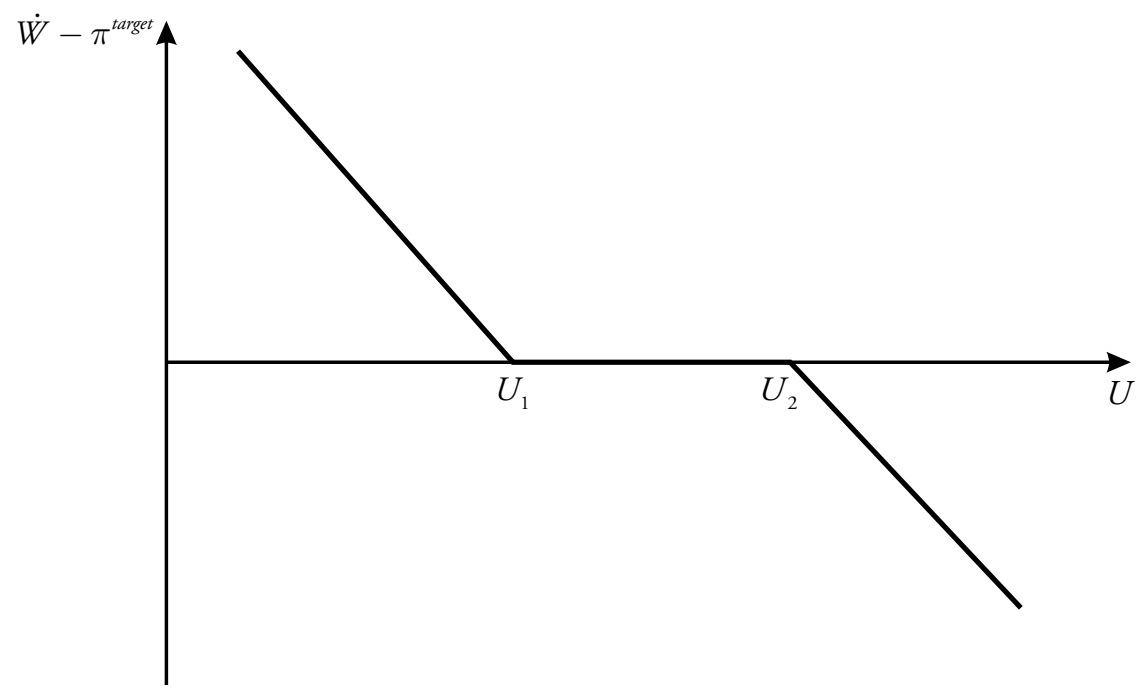

Figure 2 illustrates this argument: ${ }^{30}$ In the range between $U_{1}$ and $U_{2}$, there are multiple equilibria for stable wage inflation. If unemployment falls below $U_{1}$, labour market shortages lead to rising nominal wage pressure. If unemployment raises above $U_{2}$, centralised wage setting structures might endogenously break up. However, as nominal wages do not change anything in aggregate employment, the change in bargaining structures would not lower unemployment.

In a setting of highly coordinated wage bargaining, unions can be expected to behave similarly to monopoly unions. With the union setting the wage contract closely followed by the rest of the economy knowing that changes in the nominal wage level neither translate into real wage increases (neither for their members nor for the other unions' members) nor into changes in employment, this single union will behave as a monopoly union.

30 Please note that the NAIRU curve in the figure has to be interpreted as the original Phillips (1958) curve: The causality runs from a certain level of unemployment to an acceleration or deceleration of wage increases, not vice versa. 


\subsection{Empirics: Euro Area vs. the United States}

For the Euro area, it can be argued that wage bargaining is implicitly quite co-ordinated, even if not centralised or formally co-ordinated. Soskice/ Hancké (2002) argue that in the important core countries of EMU such as France, Germany, the Netherlands and Belgium (but not necessarily Spain or Portugal), wage setting has converged towards agreeing on wage increases in relation to the changes in relative competitiveness of main trading partners. Belgium has an explicit law to this extent. The Dutch unions for a long time have taken German wage developments into account. According to Soskice/ Hancké (2002), in France a decentralised wage setting mechanism which is centred around a few large firms exposed to foreign competition acts de facto as a centralised wage setting taking into account the relative unit labour costs developments. As Germany is the biggest economy in EMU and especially important in the export of tradable goods, these mechanisms lead to an implicit co-ordinated wage setting for EMU in which the rest of EMU follows wage developments in Germany, even though empirically the adjustment process seems to be rather slow.

Wage bargaining in Germany, on the other hand, is traditionally highly co-ordinated, even if not highly centralised. A single union for some region (usually the metal workers' union $^{31}$ ) negotiates the first contract of a wage round. The other districts follow that contract, which then is closely followed by the rest of the economy with small corrections for the other sectors' current and structural situation. If EMU wage bargaining is co-ordinated around German wage bargaining, it is in fact co-ordinated around the German pilot contract.

This argument is not necessarily invalidated by the fact that German wage increases have deviated downwards from the rest of EMU over recent years. One could argue that Germany is still the reference with the other countries in the core of EMU experiencing wage increases slightly above the German wage standard. Alternatively, one could argue that deviations over a number of years from the German standard might be possible until the loss of competitiveness forces countries back to that standard, as it has been the case in the Netherlands after the economic slump after 200I. In both cases, German wages would act as some kind of medium term wage anchor for EMU. However, if wage bargaining in the core of EMU were significantly more co-ordinated than originally thought, the NAIRU curve should be twisted as described above. ${ }^{32}$

\section{Conclusion: New Macroeconomic Responsibilities}

So what does it mean for economic policy when there is a wide range of multiple equilibria with stable prices but different rates of unemployment as it has been argued is the case for pressed in stable monetary policy target and broadly unaltered labour market institutions), time series for the Euro area are too short to use rigorous econometrical methods to test our hypothesis. 
EMU? As the trade union is not able to influence employment with its nominal wage demands anymore, it cannot be made responsible for unemployment. However, as the price level is proportional to the wage level set by wage bargainers, unions are now responsible for stable prices.

At the same time, the responsibility for output and employment shifts to the central bank: which of the points in the range $U_{1}$ to $U_{2}$ is reached depends on aggregate demand, which is influenced by the central bank's interest rate. The central bank can opt for a low employment or a high employment situation with stable prices. Thus, responsibilities between unions and central bank have switched in a set-up with strategically acting wage bargainers compared to the standard textbook theory (see table I).

Table I: Responsibilities of Macroeconomic Actors

\begin{tabular}{l|cc}
\hline & Textbook theory & This paper \\
\hline Wage bargainers & $\begin{array}{c}\text { Low real wages } \\
\text { High employment }\end{array}$ & $\begin{array}{c}\text { Low nominal wage increases } \\
\text { Low inflation }\end{array}$ \\
Central bank & $\begin{array}{c}\text { Low growth in money supply } \\
\text { Low inflation }\end{array}$ & $\begin{array}{c}\text { High aggregate demand } \\
\text { High employment }\end{array}$ \\
\hline
\end{tabular}

However, it would be overly simplified to blame the central bank alone for unemployment. If we include short-run price rigidities into the above model, an increase in nominal wages would temporarily lead to real wage gains when nominal wages increase, even though the equilibrium real wage remains unchanged. In such a set-up, a monopoly union would have an incentive to push for higher nominal wage increases. The central bank's task would then be to threaten through a potential increase in the interest rate to decrease output and employment if the union should behave inflationarily. Such a threat can be expected to work reasonably well as long as it is credible, as the trade union could only win temporarily, while the losses might be permanent. However, the central bank would have to be able to communicate this threat to the trade unions. While this communication seems to have worked reasonably well for the German Bundesbank (Hall/ Franzese 1998) because there was a clear symmetry of national monetary policy and wage setting, it is unclear how it works in EMU. While monetary policy is set at the supra-national level, wages are still negotiated at national levels, even if they might be loosely co-ordinated between some of the countries. Let alone for political reasons, the ECB would scarcely admit that it targets German wages, even if German unions were central for EMU wage developments. Thus the political set-up of EMU might at the moment contribute to the high unemployment.

The ECB's task is further complicated by the uncertainty about how wage bargaining works in EMU, especially in connection with the institutionalised macroeconomic responsibilities in EMU. The ECB has been given the primary objective of pursuing price stability. This is also the standard by which the public will judge the ECB's work. If inflation would run strongly above 2 percent, the central bankers would be blamed for their failure. The blame for unemployment, on the other hand, does not fall to the same extent 
on the ECB as the standard textbook's distribution of responsibilities between macroeconomic actors is ingrained in public conscience. Thus, it is only rational for risk-averse central bankers to choose a point close to $U_{2}$ to be on the safe side.

Improved information exchange between wage bargainers and monetary policy makers as embodied in the EMU's Macroeconomic Dialogue might help a little as it could alleviate the uncertainty and information asymmetry. However, as von Hagen / Mundschenk (200I) note, the wage bargainers in the Macroeconomic Dialogue themselves lack the possibility to enforce any possible commitment they make, as independent national and regional unions finally make decisions on wage contracts. Thus, even the dialogue by itself is not very promising to alleviate unemployment in EMU.

\section{A. Mathematical Appendix}

The wage level $W$ is uniform across all firms.

\section{A.I The Firm's Maximisation Problem}

Minimizing unit cost $u c_{i}$ by choosing the optimum combination of $K_{i} / y_{i}$ and $N_{i} / y_{i}$ under the constraint of (I) yields (5) and (6). Given this combination of labour and capital per unit of production, the firm $i$ maximises its profit:

$$
\begin{gathered}
\max _{P_{i}} \Pi=\left[P_{i}-u c_{i}\right] y_{i}^{D} \\
=\left[P_{i}-u c_{i}\right] \frac{1}{n}\left(\frac{P_{i}}{P}\right)^{-\eta} \frac{Y^{D}}{P} . \\
\frac{\partial \Pi}{\partial P_{i}}=\alpha_{i} P_{i}^{-\eta} \frac{1}{P^{-\eta}} \frac{Y^{D}}{P}-\alpha_{i} \eta\left[P_{i}-u c_{i}\right] P_{i}^{-\eta-1} \frac{1}{P^{-\eta}} \frac{Y^{D}}{P} \\
=\alpha_{i} \frac{1}{P^{-\eta}} \frac{Y^{D}}{P}\left[P_{i}^{-\eta}-\eta P_{i}^{-\eta-1}\left(P_{i}-u c_{i}\right)\right]=0 \\
\Leftrightarrow P_{i}^{-\eta}-\eta P_{i}^{-\eta-1}\left(P_{i}-u c_{i}\right)=0 \\
\Leftrightarrow(1-\eta) P_{i}^{-\eta}+\eta P_{i}^{-\eta-1} u c_{i}=0 \\
\Leftrightarrow P_{i}=\frac{-\eta}{1-\eta} u c_{i} \\
=\frac{-\eta}{1-\eta} \frac{1}{A} P^{1-\alpha} W^{\alpha}(\delta+i)^{1-\alpha}\left(\frac{\alpha^{1-\alpha}}{(1-\alpha)^{1-\alpha}}+\frac{(1-\alpha)^{\alpha}}{\alpha^{\alpha}}\right) .
\end{gathered}
$$


For the symmetric case of $P=P_{i}$ this becomes:

$$
\begin{aligned}
P_{i}^{\alpha} & =\frac{-\eta}{1-\eta} \frac{1}{A} W^{\alpha}(\delta+i)^{1-\alpha}\left(\frac{\alpha^{1-\alpha}}{(1-\alpha)^{1-\alpha}}+\frac{(1-\alpha)^{\alpha}}{\alpha^{\alpha}}\right) \\
& \Leftrightarrow P_{i}=A^{-\frac{1}{\alpha}}\left(\frac{-\eta}{1-\eta}\right)^{\frac{1}{\alpha}}(\delta+i)^{\frac{1-\alpha}{\alpha}} \frac{1}{\alpha(1-\alpha)^{\frac{1-\alpha}{\alpha}} W .}
\end{aligned}
$$

\section{A.2 Aggregate Demand and Output I: Only Workers Consume}

Assuming that all of the firms' profits and all interest incomes are saved, we get for nominal aggregate demand $Y^{D}$, aggregate real demand $y^{D}$ and output $y$ :

$$
\begin{gathered}
Y^{D}=c N^{*} W+\delta P K^{*}+P y_{0}^{D} \\
=c W\left(\frac{-\eta}{1-\eta}\right) \frac{\left(\delta+i^{K}\right)^{\frac{1-\alpha}{\alpha}}}{A^{\frac{1}{\alpha}}(1-\alpha)^{\frac{1-\alpha}{\alpha}}} \frac{Y^{D}}{P}+\delta P\left(\frac{1-\eta}{-\eta}\right) \frac{1-\alpha}{\delta+i^{K}} \frac{Y^{D}}{P}+P y_{0}^{D} \\
\Leftrightarrow Y^{D}=\frac{-\eta}{-\eta+(\eta-1)\left(c \alpha+\frac{\delta(1-\alpha)}{(\delta+i)}\right)} P y_{0}^{D} \\
\Leftrightarrow y^{D}=y^{*}=\frac{-\eta}{-\eta+(\eta-1)\left(c \alpha+\frac{\delta(1-\alpha)}{(\delta+i)}\right)} y_{0}^{D} .
\end{gathered}
$$

Substituting (37) into (I8) yields total aggregate employment:

$$
N^{*}=\left(\frac{-\eta}{1-\eta}\right)^{\frac{1-\alpha}{\alpha}} \frac{-\eta\left(\delta+i^{K}\right)^{\frac{1-\alpha}{\alpha}}}{A^{\frac{1}{\alpha}}(1-\alpha)^{\frac{1-\alpha}{\alpha}}\left(-\eta-(1-\eta)\left[c \alpha+\delta \frac{1-\alpha}{\delta+i^{K}}\right]\right)} y_{0}^{D} .
$$

Differentiating with respect to $i^{K}$ yields:

$$
\begin{aligned}
& \frac{\partial N^{*}}{\partial i^{K}}=\left(\left(\frac{-\eta}{1-\eta}\right)^{\frac{1-\alpha}{\alpha}} \eta\left(\delta+i^{K}\right)^{\frac{1-\alpha}{\alpha}}(1-\alpha)\right) \\
& \cdot\left(\frac{\delta(1-\eta)}{A^{\frac{1}{\alpha}}\left(\delta+i^{K}\right)^{2}(1-\alpha)^{\frac{1-\alpha}{\alpha}}\left(-\eta-(1-\eta)\left[c \alpha+\delta \frac{1-\alpha}{\delta+i^{K}}\right)\right)^{2}}\right. \\
& \left.-\frac{1}{\alpha\left(\delta+i^{K}\right) A^{\frac{1}{\alpha}}(1-\alpha)^{\frac{1-\alpha}{\alpha}}\left(-\eta-(1-\eta)\left[c \alpha+\delta \frac{1-\alpha}{\delta+i^{K}}\right]\right)}\right)
\end{aligned}
$$

which can be shown to be positive for positive $i^{K}$ which fulfil 
S. Dullien: Monetary Policy and Wage Bargaining Without Real Balance Effect

$$
i^{K}<\frac{\delta((\eta-1) c \alpha-1)}{\eta-\eta c \alpha+c \alpha} .
$$

Thus, in this range, a cut in the interest rate leads to increased employment.

\section{A.3 Aggregate Demand and Output II: Entrepreneurs Consume}

By subtracting the firm's wage costs and capital depreciation from its revenue, we get the profit for each firm (including interest payments):

$$
\begin{gathered}
\Pi_{i}=P_{i} y_{i}^{D}-W N_{i}^{*}-\delta K_{i}^{*} \\
=\alpha_{i} P_{i} \frac{Y^{D}}{P}-\alpha_{i} W\left(\frac{-\eta}{1-\eta}\right)^{\frac{1-\alpha}{\alpha}} \frac{\left(\delta+i^{K}\right)^{\frac{1-\alpha}{\alpha}}}{A^{\frac{1}{\alpha}}(1-\alpha)^{\frac{1-\alpha}{\alpha}}} \frac{Y^{D}}{P}- \\
\alpha_{i} \delta \frac{1-\eta}{-\eta}\left(\frac{(1-\alpha)}{\left(\delta+i^{K}\right)}\right) \frac{Y^{D}}{P} \\
\Leftrightarrow \frac{\Pi_{i}}{P}=\alpha_{i}\left[1-\frac{1-\eta}{-\eta}\left(\alpha+\delta \frac{1-\alpha}{\delta+i^{K}}\right)\right] \frac{Y^{D}}{P} .
\end{gathered}
$$

Aggregating for the whole economy yields for aggregate profits (including interest costs):

$$
\begin{gathered}
\Pi=\sum \Pi_{i}=\sum \alpha_{i}\left[1-\frac{1-\eta}{-\eta}\left(\alpha+\delta \frac{1-\alpha}{\delta+i^{K}}\right)\right] Y^{D} \\
=\left[1-\frac{1-\eta}{-\eta}\left(\alpha+\delta \frac{1-\alpha}{\delta+i^{K}}\right)\right] Y^{D} .
\end{gathered}
$$

Assuming that rentiers and entrepreneurs consume a share $c_{\Pi}$ of their income yields for aggregate demand $Y^{D+}$ and output $y^{*+}$ :

$$
\begin{gathered}
Y^{D+}=c N^{*} W+c_{\Pi}\left(1-\frac{1-\eta}{-\eta}\left(\alpha+\delta \frac{1-\alpha}{\delta+i^{K}}\right)\right) Y^{D+} \\
+\delta P K^{*}+P y_{0}^{D} \\
=c W\left(\frac{-\eta}{1-\eta}\right) \frac{\left(\delta+i^{K}\right)^{\frac{1-\alpha}{\alpha}}}{A^{\frac{1}{\alpha}}(1-\alpha)^{\frac{1-\alpha}{\alpha}}} \frac{Y^{D+}}{P}+ \\
c_{\Pi}\left(1-\alpha \frac{1-\eta}{-\eta}\right) Y^{D+}
\end{gathered}
$$




$$
\begin{gathered}
+\left(1-c_{\Pi}\right) \delta P\left(\frac{1-\eta}{-\eta}\right) \frac{1-\alpha}{\delta+i^{K}} \frac{Y^{D+}}{P}+P y_{0}^{D} \\
\Leftrightarrow \frac{\left(-\eta-(1-\eta)\left[c \alpha+\left(1-c_{\Pi}\right) \delta \frac{1-\alpha}{\delta+i^{K}}\right]-c_{\Pi}(-\eta-\alpha+\alpha \eta)\right)}{-\eta} Y^{D+}=P y_{0}^{D} \\
y^{*+}=\frac{-\eta}{\left(-\eta-(1-\eta)\left[c \alpha+\left(1-c_{\Pi}\right) \delta \frac{1-\alpha}{\delta+i^{K}}\right]-c_{\Pi}(-\eta-\alpha+\alpha \eta)\right)} y_{0}^{D} .
\end{gathered}
$$

Thus, only the multiplier changes. The basic notion that changes in the nominal wage do not lead to changes in real output remains intact.

\section{A.4 Degree of Monopolisation, Real Wages and Output}

The elasticity of substitution in the consumers' CES utility function $\eta$ can also been interpreted as the inverse degree of the firms' monopoly power (Blanchard/Giavazzi 2000). A number of interesting results can be concluded from this fact. It can be shown that both the real wage and aggregate output increase with a fall in the degree of the firms' monopoly power (an increase of $\eta$ ):

$$
\begin{gathered}
\frac{\partial y^{*}}{\partial \eta}=\left[-\frac{1}{-\eta+(\eta-1)\left(c \alpha \frac{\delta(1-\alpha)}{\delta+i^{K}}\right)}+\frac{\eta\left(c \alpha+\frac{\delta(1-\alpha)}{\delta+i^{K}}-1\right)}{\left(-\eta+(\eta-1)\left(c \alpha+\frac{\delta(1-\alpha)}{\delta+i^{K}}\right)\right)^{2}}\right] y_{0}^{D} \\
=\frac{c \alpha+\frac{\delta(1-\alpha)}{\delta+i^{K}}}{\left(-\eta+(\eta-1)\left(c \alpha+\frac{\delta(1-\alpha)}{\delta+i^{K}}\right)\right)^{2}} y_{0}^{D}>0 . \\
\frac{\partial W / P}{\partial \eta}=\alpha A^{\frac{1}{\alpha}} \frac{(1-\alpha)^{\frac{1-\alpha}{\alpha}}}{\left(\delta+i^{K}\right)^{\frac{1-\alpha}{\alpha}}} \frac{1}{\alpha}\left(\frac{1-\eta)^{\frac{1-\alpha}{\alpha}}}{-\eta} \frac{1}{\eta^{2}}\right. \\
=A^{\frac{1}{\alpha}}\left(\left(\frac{1-\eta}{-\eta}\right)\left(\frac{(1-\alpha)}{\left(\delta+i^{K}\right)}\right)^{\frac{1-\alpha}{\alpha}} \frac{1}{\eta^{2}}>0 .\right.
\end{gathered}
$$

\section{References}

Barth, Marvin J. / Ramey, Valerie A. (200I): The Cost Channel of Monetary Transmission, in: NBER Macroeconomics Annual, Vol. 16, pp. 199-239

Betz, Karl (200I): Jenseits der Konjunkturpolitik. Überlegungen zur langfristigen Wirtschaftspolitik in einer Geldwirtschaft, Marburg: Metropolis

Beyer, Andreas / Farmer, Roger E. A. (2002): Natural Rate Doubts, ECB Working Paper, No. I2I 
Blanchard, Olivier J. / Fischer, Stanley (1989): Lectures on Macroeconomics, Cambridge, MA.: MIT Press

Blanchard, Olivier J./ Giavazzi, Francesco (2000): Macroeconomic Effects of Regulation and Deregulation in Goods and Labour Markets, MIT Department of Economics Working Paper, No. OI-O2

Blanchard, Olivier J. / Kiyotaki, Nobuhiro (1987): Monopolistic Competition and the Effects of Aggregate Demand, in: American Economic Review, Vol. 77, No. 4, pp. 648-666

Blanchard, Olivier J. / Summers, Larry (1987): Hysteresis in Unemployment, in: European Economic Review, Vol. 3I, No. I-2, pp. 288-295

Burda, Michael / Wyplosz, Charles (1997): Macroeconomics. A European Text, Oxford: Oxford University Press

Carlin, Wendy/Soskice, David (1990): Macroeconomics and the Wage Bargain. A Modern Approach to Employment, Inflation, and the Exchange Rate, Oxford: Oxford University Press

Clarida, Richard / Galí, Jordi / Gertler, Michael (1999): The Science of Monetary Policy: A New Keynesian Perspective, in: Journal of Economic Literature, Vol. 37, No. 4, pp. 166I-1707

Collignon, Stefan (1999): Unemployment, Wage Developments and the Economic Policy Mix in Europe, in: Empirica, Vol. 26, No. 3, pp. 259-269

Collignon, Stefan (2002): Monetary Stability in Europe, London: Routledge

Coricelli, Fabrizio / Cukierman, Alex / Dalmazzo, Alberto (200o): Monetary Institutions, Monopolistic Competition, Unionized Labor Markets and Economic Performance, CEPR Discussion Paper, No. 2745

Dixit, Avinash K. / Stiglitz, Joseph E. (1977): Monopolistic Competition and Optimum Product Diversity, in: American Economic Review, Vol. 67, No. 3, pp. 297-308

Dullien, Sebastian (2004): The Interaction of Monetary Policy and Wage Bargaining in the European Monetary Union - Lessons from the Endogenous Money Approach, Houndmills / New York: MacMillan Palgrave

Fischer, Stanley (1977): Long-Term Contracts, Rational Expectations, and the Optimal Money Supply Rule, in: Journal of Political Economy, Vol. 85, No. I, pp. I9I-205

Galbraith, James K. (1997): Time to Ditch the NAIRU, in: Journal of Economic Perspectives, Vol. II, No. I, pp. 93-108

Grilli, Vittorio/Masciandaro, Donato/Tabellini, Guido (I99I): Political and Monetary Institutions and Public Finance Policies in the Industrial Countries, in: Economic Policy, Vol. 6, No. 13, pp. 34I-392

Hagen, Jürgen von / Mundschenk, Susanne (200I): The Functioning of Economic Policy Coordination, ZEI Working Paper, No. Bo8-200I

Hall, Peter A. / Franzese, Robert A. (1998): Mixed Signals: Central Bank Independence, Coordinated Wage Bargaining, and European Monetary Union, in: International Organization, Vol. 52, No. 3, pp. 505-535

Heijdra, Ben J./ van der Ploeg, Frederick (2002): The Foundations of Modern Macroeconomics, Oxford: Oxford University Press

Keynes, John M. (1930): A Treatise on Money, London: Macmillan 
Keynes, John M. (1936): The General Theory of Employment, Interest, and Money, New York: Harcourt Brace

Lucas, Robert E. (1972): Expectations and the Neutrality of Money, in: Journal of Economic Theory, Vol. 4, No. 2, pp. IO3-I24

Lucas, Robert E. (1973): Some International Evidence on Output-Inflation Tradeoffs, in: American Economic Review, Vol. 63, No. 3, pp. 326-344

Lucas, Robert E. (1976): Econometric Policy Evaluation. A Critique, in: Carnegie-Rochester Conference Series on Public Policy, Vol. I, pp. 19-46

McCallum, Bennett T. (1989): Monetary Economics. Theory and Policy, New York: Macmillan

Moore, Basil J. (1989): A Simple Model of Bank Intermediation, in: Journal of Post Keynesian Economics, Vol. I2, No. 2, pp. 139-162

Nelson, Charles R. / Plosser, Charles I. (1982): Trends and Random Walks in Macroeconomic Time Series: Some Evidence and Implications, in: Journal of Monetary Economics, Vol. Io, No. 2, pp. 139-162

Phillips, Alban W. (1958): The Relationship Between Unemployment and the Rate of Change of Money Wages in the United Kingdom, I86I-1957, in: Economica, Vol. 25, No. 2, pp. 283-299

Riese, Hajo (1986): Theorie der Inflation, Tübingen: Mohr

Rogoff, Kenneth (1985): The Optimal Degree of Commitment to an Intermediate Monetary Target, in: Quarterly Journal of Economics, Vol. Ioo, No. 4, pp. II69-II89

Romer, David (1996): Advanced Macroeconomics, New York: McGraw-Hill

Romer, David (1999): Short-Run Fluctuations, Berkeley: University of California

Romer, David (2000): Keynesian Macroeconomics Without the LM Curve, NBER Working Paper, No. 746I

Samuelson, Paul A. / Solow, Robert M. (1960): Analytical Aspects of Anti-Inflation Policy, in:

American Economic Review. Papers and Proceedings, Vol. 50, No. 2, pp. 177-194

Sinn, Hans-Werner (2003): Ist Deutschland noch zu retten?, Berlin: Econ

Soskice, David / Hancké, Bob (2002): Gently Turning. The Political Economy of EMU, Report for Project »Institutionen, Wirtschaftswachstum und Beschäftigung in der EWU«, Düsseldorf: Hans-Böckler-Stiftung

Soskice, David/Iversen, Torben (2000): The Non-Neutrality of Monetary Policy with Large Price Setters, in: Quarterly Journal of Economics, Vol. II5, No. I, pp. 265-284

Taylor, John B. (1980): Aggregate Dynamics and Staggered Contracts, in: Journal of Political Economy, Vol. 88, No. I, pp. I-23

Wray, L. Randall (1990): Money and Credit in Capitalist Economies. The Endogenous Money Approach, Hants, GB: Elgar 